\title{
PENGARUH ROA, ROE, NPM DAN EPS TERHADAP HARGA SAHAM PERUSAHAAN DI JAKARTA ISLAMIC INDEX (JII) PERIODE 2011-2015.1)
}

\author{
Rinaldi Triawan \\ Program Studi S1Ekonomi Islam-Fakultas Ekonomi dan Bisnis-Universitas Airlangga \\ Email : rinaldi.triawan-12@feb.unair.ac.id \\ Atina Shofawati \\ Departemen Ekonomi Syariah-Fakultas Ekonomi dan Bisnis-Universitas Airlangga \\ Email : atina-o@feb.unair.ac.id
}

\begin{abstract}
ABSTRACK:
The purpose of this research is to analyze and test the effect of financial performance is reflected from profitability ratio to price stock in Jakarta Islamic Index of period 2011-2015. This research is a quantitative approach that use a data panel regression analysis. The result of this research show that in partially from four independent variables is that Return On Assets, Return On Equity, Net Profit Margin and Earning Per Share, only Earning Per Share has a significant influence to stock price in Jakarta Islamic Index. The result of all variables simultaneously, Return On Assets, Return On Equity, Net Profit Margin and Earning Per Share have significant influence to stock price in Jakarta Islamic.
\end{abstract}

\section{Keywords: ROA, ROE, NPM, EPS}

\section{PENDAHULUAN}

Setiap orang memiliki pilihan untuk menentukan dana atau vang yang mereka miliki untuk konsumsi saat ini atau konsumsi masa depan. Investasi adalah komitmen atas sejumlah dana atau sumber daya lainnya yang dilakukan pada saat ini, dengan tujuan memperoleh sejumlah keuntungan di masa datang (Tandelilin, 2010:2).

Keberadaan pasar modal dalam perekonomian suatu negara memiliki peranan yang penting sebagai sarana berinvestasi. Pasar modal dapat melakukan pemindahan dana dari pihak yang kelebihan dana kepada pihak yang kekurangan dana tentunya dengan mendapatkan sekuritas dan harapan memperoleh imbalan (return), sedangkan perusahaan sebagai pihak yang mendapatkan dana dapat memanfaatkan dana tersebut untuk mengembangkan perusahaannya. Pasar modal khususnya pasar saham merupakan pasar bagi para pengusaha dan investor dimana pihak satu memerlukan dana dan pihak lainnya menanamkan dana (Harto, 2007:1).

Untuk mengetahui apakah saham suatu perusahaan layak dijadikan pilihan investasi, maka sebelumnya harus dilakukan analisis terhadap perusahaan bersangkutan. Hasil analisis tersebut harus bisa memberikan gambaran kepada investor tentang nilai perusahaan tersebut (Tandelilin, 2010:363). Adapun penilaian seorang investor terhadap suatu saham ada empat, sebagai berikut: (1) dengan melihat prospek usaha yang menjanjikan, (2) kinerja keuangan dan non keuangan yang baik, (3) penyajian laporan kevangan yang terbuka dan jelas, (4) dan terlihatnya sisi keuntungan yang terus meningkat (Fahmi, 2012:91). 
Triawan, et al/ Jurnal Ekonomi Syariah Teori dan Terapan Vol. 5 No. 7 Juli 2018: 541-555;

PENGARUH ROA, ROE, NPM DAN EPS TERHADAP HARGA SAHAM DI JAKARTA ISLAMIC INDEX (JII) PERIODE 2011-2015

Informasi yang terdapat pada laporan kevangan sangat berguna bagi pihak-pihak yang mempunyai kepentingan di perusahaan tersebut, bagi manajer sebagai pihak internal perusahaan menggunakan laporan kevangan sebagai dasar pengukuran kinerja perusahaan. Bagi investor sebagai pihak eksternal perusahaan menggunakan laporan keuangan untuk mengukur besar profit yang didapatkan.

Return On Assets (ROA) menggambarkan sejauh mana kemampuan aset-aset yang dimiliki perusahaan bisa menghasilkan laba. Return On Equity (ROE) menggambarkan sejauh mana kemampuan perusahaan menghasilkan laba yang bisa diperoleh pemegang saham (Tandelilin, 2010:372). Profit Margin digunakan untuk mengukur margin laba atas penjualan (Kasmir, 2014:199). Laba per lembar saham menunjukkan besarnya laba bersih perusahaan yang siap dibagikan bagi semua pemegang saham perusahaan (Tandelilin, 2010:373).

Pada penelitian ini bertujuan untuk menganalisis dan menguji pengaruh kinerja kevangan perusahaan yang tercermin dari ROA, ROE, NPM dan EPS terhadap Harga Saham pada perusahaan yang terdaftar di Jakarta Islamic Index periode 2011-2015. Variabel yang peneliti gunakan antara lain rasio Return On Assets (ROA), Return On Equity (ROE), Net Profit Margin (NPM) dan Earning Per Share (EPS).
Data dalam penelitian ini adalah data tahunan. Dimana data Harga Saham diperoleh dari closing price yaitu harga penutupan akhir tahun pada bulan Desember setiap tahunnya dengan mengakses Yahoo Finance, sedangkan data Return On Assets (ROA), Return On Equity (ROE), Net Profit Margin (NPM), dan Earning per Share (EPS), adalah data laporan keuangan tahunan perusahaan yaitu dari 2011-2015. Adapun perusahaan yang diteliti dalam penelitian ini adalah perusahaan yang terdaftar dalam Jakarta Islamic Index secara berturut-turut dalam periode 2011-2015.

Berdasarkan latar belakang tersebut, maka peneliti dapat merumuskan masalah yaitu: Apakah terdapat pengaruh secara parsial variabel ROA, ROE, NPM dan EPS terhadap variabel harga saham perusahaan di Jll pada periode 2011-2015? Apakah terdapat pengaruh secara simultan variabel ROA, ROE, NPM dan EPS terhadap variabel harga saham perusahaan di JII pada periode 2011-2015?

Adapun tujuan dari penelitian ini adalah untuk mengetahui seberapa besar pengaruh variabel ROA, ROE, NPM dan EPS terhadap variabel harga saham perusahaan di Jll periode 2011-2015 baik secara parsial maupun secara simultan.

\section{LANDASAN PUSTAKA DAN HIPOTESIS}

Investasi berasal dari kata invest yang berarti menanam atau menginvestasikan vang atau modal (Dyah dan Suratman, 2009:3). Investasi dapat dilakukan di pasar vang seperti investasi T-bill dan dapat 
Triawan, et al/ Jurnal Ekonomi Syariah Teori dan Terapan Vol. 5 No. 7 Juli 2018: 541-555;

PENGARUH ROA, ROE, NPM DAN EPS TERHADAP HARGA SAHAM DI JAKARTA ISLAMIC INDEX

(JII) PERIODE 2011-2015

dilakukan di pasar modal seperti T-bond,

jenis efek yang diperdagangkan dan

saham preferen, dan saham biasa (Fahmi,

2012:3). Pada dasarnya tujuan orang melakukan investasi adalah untuk menghasilkan sejumlah vang (meningkatkan kesejahteraan investor) (Tandelilin, 2010:7).

Hampir seluruh negara di dunia memiliki Pasar modal sebagai sarana untuk berinvestasi. Pengertian Pasar modal dalam arti sempit merupakan kegiatan yang mempertemukan penjual (perusahaan) dan pembeli (investor) dana jangka panjang (Sjahrial, 2012:13). Pasar modal menurut Tandelilin (2010:26) adalah pertemuan antara pihak yang memiliki kelebihan dana dengan pihak yang membutuhkan dana dengan cara memperjualbelikan sekuritas. Pasar modal menurut undang-undang No. 8 tahun 1995 tentang pasar modal pasal 1 ayat 13 adalah:

Kegiatan yang bersangkutan dengan penawaran umum dan perdagangan Efek, Perusahaan publik yang berkaitan dengan Efek yang diterbitkannya, serta lembaga dan profesi yang berkaitan dengan Efek.

Pasar modal juga dikenal sebagai bursa efek. Bursa Efek menurut pasal 1 ayat 4 undang-undang No. 8 tahun 1995 tentang pasar modal adalah:

pihak yang menyelenggarakan dan menyediakan sistem dan/atau sarana untuk mempertemukan penawaran jual dan beli Efek pihak-pihak lain dengan tujuan memperdagangkan Efek diantara mereka.

Pasar modal syariah adalah pasar modal yang seluruh mekanisme kegiatannya terutama mengenai emiten 
Triawan, et al/ Jurnal Ekonomi Syariah Teori dan Terapan Vol. 5 No. 7 Juli 2018: 541-555;

PENGARUH ROA, ROE, NPM DAN EPS TERHADAP HARGA SAHAM DI JAKARTA ISLAMIC INDEX

(JII) PERIODE 2011-2015

arahan Dewan Pengawas Syariah PT DIM,

ada 4 syarat (business sreening) yang

harus dipenuhi agar saham-saham

tersebut dapat masuk ke Jll (Sutedi, 2011:64):

1) Emiten tidak menjalankan usaha perjudian dan permainan yang tergolong judi atau perdagangan yang dilarang. 2) Bukan lembaga keuangan konvensional yang menerapkan system riba, termasuk perbankan dan asuransi konvensional. 3) Usaha yang dilakukan bukan memproduksi, mendistribusikan, dan memperdagangkan makanan/minuman yang haram. 4) Tidak menjalankan usaha memproduksi, mendistribusikan, dan menyediakan barang/jasa yang merusak moral dan bersifat mudharat.

Selain business screening, screening saham syariah juga dilakukan tahap financial screening. Tahap financial screening mempertimbangkan rasio total utang berbasis bunga dibandingkan total asset tidak lebih dari $45 \%$, dan rasio total pendapatan bunga dan total pendapatan tidak halal lainnya dibandingkan total pendapatan usaha dan total pendapatan lainnya tidak lebih dari 10\% (www.syariahsaham.com). Selain filter syariah, dalam proses pemilihan saham yang masuk ke dalam JII, Bursa Efek Indonesia juga melakukan tahaptahap pemilihan yang mempertimbangkan aspek likuiditas dan kondisi keuangan emiten.

Saham adalah pernyataan kepemilikan suatu perusahaan. Saham terbagi kedalam 2 jenis: Saham biasa (common stock) adalah sertifikat yang menunjukkan bukti kepemilikan suatu perusahaan (Tandelilin, 2010:32). Saham istimewa (preferred stock) adalah surat berharga yang dijual oleh suatu perusahaan dimana pemegangnya akan memperoleh pendapatan tetap dalam bentuk dividen yang akan diterima setiap kuartal (tiga bulanan) (Fahmi, 2012:86). Pihak yang memiliki saham akan memperoleh keuntungan sebagai bentuk kewajiban yang diterima yaitu: memperoleh dividen, memperoleh keuntungan modal (capital gain) dan memiliki hak suara bagi pemegang saham biasa (Fahmi, 2012:88).

Harga saham adalah harga yang terbentuk di pasar yang besarannya dipengaruhi oleh hukum permintaan dan penawaran. Investor akan menjual saham ketika melihat ada kecenderungan harga saham akan menurun (Samsul, 2015:197). Indeks harga saham adalah indikator yang menunjukkan pergerakan harga saham (Darmadji dan Fakhruddin, 2011:129). Faktor-faktor yang mempengaruhi harga saham secara fundamental dipengaruhi oleh kinerja perusahaan dan kemungkinan risiko yang dihadapi perusahaan. Kinerja perusahaaan tercermin dari laba operasional dan laba bersih per saham serta beberapa rasio keuangan yang menggambarkan kekuatan manajemen dalam mengelola perusahaan. Kinerja perusahaan dan risiko yang dihadapi dipengaruhi oleh faktor makro dan mikro ekonomi (Samsul, 2006:200).

Profitabilitas adalah hasil bersih dari serangkaian kebijakan dan keputusan (Brigham dan Houston 2001:89). Rasio 
Triawan, et al/ Jurnal Ekonomi Syariah Teori dan Terapan Vol. 5 No. 7 Juli 2018: 541-555;

PENGARUH ROA, ROE, NPM DAN EPS TERHADAP HARGA SAHAM DI JAKARTA ISLAMIC INDEX (JII) PERIODE 2011-2015

Profitabilitas mengukur efektivitas manajemen yang ditunjukkan oleh laba yang dihasilkan dari penjualan dan investasi perusahaan (Weston dan Copeland, 1988:225). Tujuan penggunaan Rasio Profitabilitas bagi perusahaan, maupun bagi pihak luar perusahaan menurut Kasmir (2014:197):

Untuk mengukur atau menghitung laba yang diperoleh perusahaan; Untuk menilai laba perusahaan tahun sebelumnya dengan tahun sekarang; Untuk menilai perkembangan laba dari waktu ke waktu; Untuk menilai besarnya laba bersih sesudah pajak dengan modal sendiri; Untuk mengukur produktivitas seluruh dana perusahaan yang digunakan baik modal pinjaman maupun modal sendiri.

Adapun manfaat Rasio Profitabilitas menurut Kasmir (2014:198):

Mengetahui besarnya tingkat laba yang diperoleh perusahaan; Mengetahui posisi laba perusahaan tahun sebelumnya dengan tahun sekarang; Mengetahui perkembangan laba dari waktu ke waktu; Mengetahui besarnya laba bersih sesudah pajak dengan modal sendiri; Mengetahui produktivitas dari seluruh dana perusahaan yang digunakan baik modal pinjaman maupun modal sendiri.

Menurut Kasmir (2014:199), jenis-jenis Rasio Profitabilitas yang dapat digunakan adalah: Profit Margin (Profit Margin on Sales), Return On Investment (ROI) atau Return On Assets (ROA), Return On Equity (ROE), dan laba per lembar saham (EPS).

ROA menggambarkan sejauh mana kemampuan asset-asset yang dimiliki perusahaan bisa menghasilkan laba. Mengukur ROA dapat menggunakan rumus sebagai berikut (Kasmir, 2014:201):

$\mathrm{ROA}=\underline{\text { Earning after Interest and Tax }} \times 100 \%$ Total Assets 
Triawan, et al/ Jurnal Ekonomi Syariah Teori dan Terapan Vol. 5 No. 7 Juli 2018: 541-555;

PENGARUH ROA, ROE, NPM DAN EPS TERHADAP HARGA SAHAM DI JAKARTA ISLAMIC INDEX (JII) PERIODE 2011-2015

Berdasarkan rumusan masalah dan tujuan penelitian ini, melahirkan hipotesis sebagai berikut: 1) ROA, ROE, NPM, dan EPS berpengaruh secara parsial terhadap harga saham perusahaan di Jll pada periode 2011-2015. 2) ROA, ROE, NPM, dan EPS berpengaruh secara simultan terhadap harga saham perusahaan di JII periode 2011-2015.

\section{METODE PENELITIAN}

\section{A. Pendekatan Penelitian}

Pendekatan yang digunakan dalam penelitian ini adalah pendekatan kuantitatif, yang menitikberatkan pada pengujian hipotesis, pengukuran data, dan pembuatan kesimpulan. Uji statistik yang digunakan dalam analisis ini adalah metode regresi data panel dan data yang diperoleh didapat dari Indonesian Stock Exchange (IDX) dengan mengakses www.idx.co.id periode waktu tahun 20112015.

\section{B. Identifikasi Variabel}

Terdapat dua jenis variabel dalam penelitian ini yaitu variabel independen (variabel bebas) dan variabel dependen (variabel terikat). Variabel independen merupakan variabel yang mempengaruhi atau yang menjadi sebab perubahannya atau timbulnya variabel dependen (terikat). Pada penelitian ini yang menjadi variabel independen adalah: ROA, ROE, NPM dan EPS. Variabel dependen merupakan variabel yang dipengaruhi atau yang menjadi akibat, karena adanya variabel bebas (Sugiyono, 2014:59). Pada penelitian ini yang menjadi veriabel dependen adalah harga saham perusahaan tahun 2011-2015 yang konsisten masuk dalam JII.

\section{Definisi Operasional Variabel}

Return On Assets (ROA) adalah kemampuan perusahaan dalam menghasilkan laba bersih sesudah pajak dibandingkan dengan total assets yang dimiliki perusahaan (Kasmir, 2014:202). Return On Asset dihitung dalam satuan persen (\%). Nilai Return On Asset (ROA) dalam penelitian ini adalah return pertahun dimulai tahun 2011 sampai return tahun 2015. Return On Equity (ROE) adalah kemampuan perusahaan dalam menghasilkan laba bersih sesudah pajak dibandingkan dengan total ekuitas yang dimiliki perusahaan (Kasmir, 2014:204). Return On Equity dihitung dalam satuan persen (\%). Nilai Return On Equity (ROE) dalam penelitian ini adalah return pertahun dimulai tahun 2011 sampai return tahun 2015. Net Profit Margin (NPM) menunjukkan laba bersih sesudah pajak yang mampu dihasilkan perusahaan dari Sales (Kasmir, 2014:200). Net Profit yang tinggi menunjukkan kemampuan perusahaan dalam menghasilkan laba yang tinggi. Net Profit Margin dalam penelitian ini dihitung dalam satuan persen (\%) pertahun dimulai profit tahun 2011 sampai profit tahun 2015. Earning per Share (EPS) atau pendapatan per lembar saham adalah bentuk pemberian keuntungan yang diberikan kepada para pemegang saham dari setiap lembar saham yang dimiliki (Kasmir, 2014:207). EPS dalam penelitian ini dihitung setiap tahun dimulai tahun 2011 sampai tahun 2015. 
Triawan, et al/ Jurnal Ekonomi Syariah Teori dan Terapan Vol. 5 No. 7 Juli 2018: 541-555;

PENGARUH ROA, ROE, NPM DAN EPS TERHADAP HARGA SAHAM DI JAKARTA ISLAMIC INDEX (JII) PERIODE 2011-2015

Harga saham yang digunakan dalam penelitian ini adalah harga saham penutupan (closing price) setiap akhir tahun, dimulai closing price tahun 2011 sampai closing price tahun 2015.

\section{Jenis dan Sumber Data}

Jenis data yang digunakan dalam penelitian ini adalah data sekunder. Data sekunder merupakan data yang diperoleh peneliti secara tidak langsung dari subyek penelitian. Data diperoleh dari mengakses website www.idx.co.id dan laporan keuangan yang diinformasikan. Laporan keuangan yang digunakan dalam penelitian ini menyangkut Return On Assets (ROA), Return On Equity (ROE), Net Profit Margin (NPM), dan Earning per Share (EPS), menggunakan data laporan keuangan tahunan. Data lainnya yang diperlukan dalam penelitian ini adalah data tahunan closing price harga saham para emiten yang terdaftar dalam Jakarta Islamic Index (JII) tahun 2011-2015 dengan mengakses Yahoo Finance.

\section{E. Populasi dan Sampel}

Populasi adalah kumpulan dari individu dengan kualitas serta ciri-ciri yang telah ditetapkan (Anshori dan Iswati, 2009:92). Menurut Sugiyono (2014:115) populasi adalah wilayah generalisasi yang terdiri atas: obyek atau subyek yang mempunyai kualitas dan karakteristik tertentu yang ditetapkan oleh peneliti untuk dipelajari dan kemudian ditarik kesimpulannya. Peneliti menetapkan populasi dalam penelitian ini adalah seluruh saham-saham syariah yang tercatat dalam JII berturut-turut selama periode 2011-2015 yaitu terdiri dari 15 perusahaan. Sampel adalah bagian dari jumlah dan karakteristik yang dimiliki oleh populasi tersebut (Sugiyono, 2014:116). Penelitian ini menggunakan sampling jenuh atau sampling sensus dimana semua anggota populasi dijadikan sampel penelitian. Hal ini dilakukan karena jumlah populasi yang relatif sedikit, kurang dari 30 (Sugiyono, 2014:123). Jumlah saham syariah yang menjadi sampel dalam penelitian ini ada 15 perusahaan. Jumlah semua sampel secara keseluruhan adalah 75 yang diambil dari data 15 perusahaan yang berturut-turut terdaftar selama periode penelitian 5 tahun dari tahun 2011-2015.

\section{F. Teknik Analisis}

Teknik analisis yang digunakan dalam penelitian ini adalah regresi data panel. Data panel adalah gabungan antara data runtut waktu (time series) dan data silang (cross section) (Basuki dan Prawoto, 2016:275). Penelitian ini menggunakan regresi data panel karena gabungan antara data runtut waktu dan data silang serta untuk mengukur pengaruh variabel independen terhadap variabel dependen. Pengolahan dan analisis data dilakukan dengan menggunakan software Eviews 9. Data panel merupakan data yang sangat bermanfaat karena data jenis ini membantu peneliti untuk mendalami kegiatan pelaku ekonomi tidak hanya antara individu tetapi perilaku ekonomi lintas waktu (Ekananda, 2016:1).

Dalam metode estimasi model regresi dengan menggunakan data panel dapat 
Triawan, et al/ Jurnal Ekonomi Syariah Teori dan Terapan Vol. 5 No. 7 Juli 2018: 541-555;

PENGARUH ROA, ROE, NPM DAN EPS TERHADAP HARGA SAHAM DI JAKARTA ISLAMIC INDEX (JII) PERIODE 2011-2015

dilakukan dengan tiga pendekatan,

antara lain: Common effect model (CEM), Fixed effect model (FEM), Random effect model (REM) (Basuki dan Prawoto, 2016:277). Untuk memilih model yang paling tepat digunakan dalam mengelola data panel, terdapat beberapa pengujian yang dapat dilakukan (Basuki dan Prawoto, 2016:277), antara lain Chow test merupakan pengujian untuk menentukan model fixed effect atau common effect yang paling tepat digunakan dalam mengestimasi data panel (Basuki dan Prawoto, 2011:294). Hausman test adalah pengujian statistik untuk memilih apakah model fixed effect atau random effect yang paling tepat digunakan (Yamin dkk, 2011:210).

Setelah mendapatkan model regresi data panel yang tepat lalu dilakukan uji signifikansi untuk mengetahui pengaruh variabel independen terhadap variabel dependen yang terdiri dari Uji F, Uji † dan Uji $R^{2}$. Uji $F$ dalam analisis regresi linier berganda bertujuan untuk mengetahui pengaruh variabel independen secara simultan yang ditunjukkan dalam table Anova (Basuki dan Prawoto, 2016:51). Uji † adalah uji yang biasanya digunakan oleh para ahli ekonometrika untuk menguji hipotesis tentang koefisien-koefisien slope regresi secara individual (Sarwoko, 2005:65). Koefisiensi determinasi $\left(R^{2}\right)$ mencerminkan seberapa besar variasi dari variabel terikat $Y$ dapat diterangkan oleh variabel bebas X (Nachrowi dan Usman, 2006:20).

\section{HASIL DAN PEMBAHASAN}

Pada metode estimasi model regresi dengan menggunakan data panel dapat dilakukan dengan tiga pendekatan, antara lain Common Effect Model (CEM), Fixed Effect Model (FEM) dan Random Effect Model (REM). Berikut ini merupakan hasil regresi dengan menggunakan ketiga model estimasi data panel.

Tabel 1.

Hasil Regresi Data Panel dengan Tiga Model

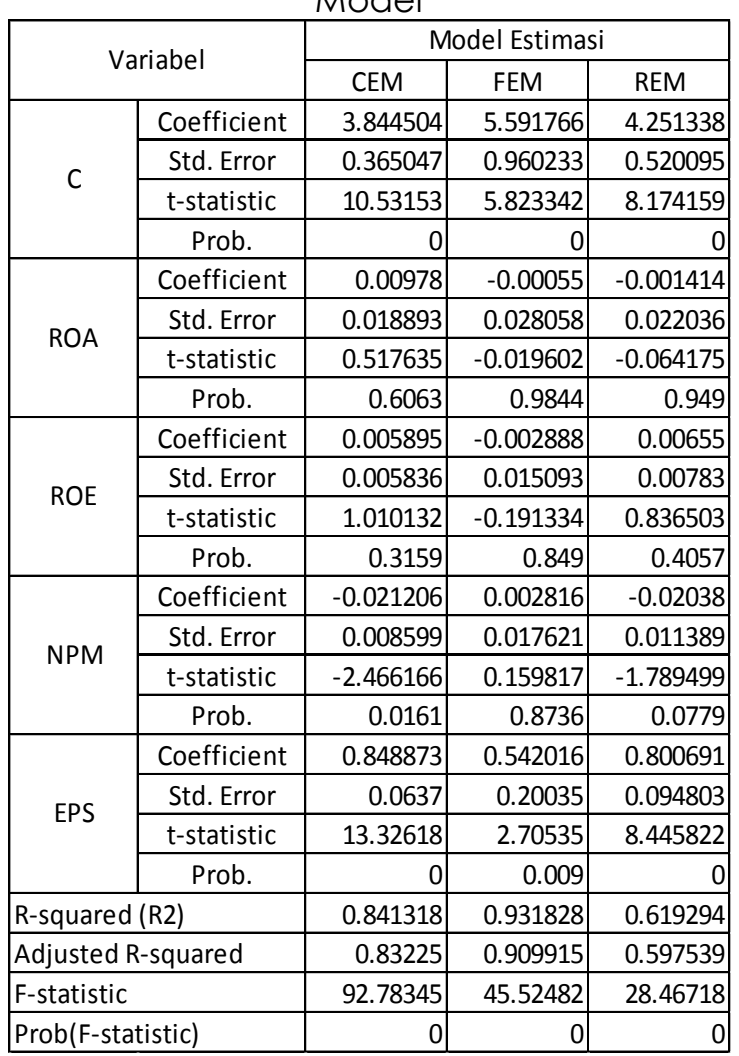

Sumber: Hasil Regresi Eviews 9, diolah

Terdapat dua jenis pengujian yang dilakukan untuk menentukan model estimasi yang paling tepat digunakan dalam mengelola data panel, yaitu uji chow untuk menentukan model fixed effect atau common effect yang paling tepat digunakan dan uji hausman untuk menentukan model fixed effect atau random effect yang paling tepat digunakan. Pengujian ini dilakukan setelah 
Triawan, et al/ Jurnal Ekonomi Syariah Teori dan Terapan Vol. 5 No. 7 Juli 2018: 541-555;

PENGARUH ROA, ROE, NPM DAN EPS TERHADAP HARGA SAHAM DI JAKARTA ISLAMIC INDEX

(JII) PERIODE 2011-2015

mengetahui hasil pengujian regresi data

panel dari masing-masing model. Hipotesis

dalam uji chow adalah sebagai berikut

(Basuki dan Prawoto, 2016:294):

$\mathrm{H}_{0}$ : Model common effect

$\mathrm{H}_{1}$ : Model fixed effect

Apabila nilai probabilitas hasil uji chow kurang dari tingkat signifikansi $(5 \%)$ yang digunakan dalam penelitian ini maka $\mathrm{H}_{0}$ ditolak dan $\mathrm{H}_{1}$ diterima sehingga fixed effect lebih tepat digunakan demikian juga sebaliknya. Berikut hasil uji chow dengan EViews 9.

Tabel 2.

Hasil Uji Chow

Ređundant Fixed Effects Tests

Pool: Untitled

Test cross-section fixed effects

\begin{tabular}{lrrr}
\hline \hline Effects Test & Statistic & d.f. & Prob. \\
\hline \hline Cross-section F & 5.310630 & $(14,56)$ & 0.0000 \\
Cross-section Chi-square & 63.364680 & 14 & 0.0000 \\
\hline \hline
\end{tabular}

Sumber: Hasil Regresi Eviews 9

Bedasarkan table hasil uji chow diatas menunjukkan bahwa probabilitas crosssection $F$ sebesar 0,0000 $<0,05$ (dengan tingkat signifikansi 5\%) sehingga berdasarkan hasil uji tersebut dapat disimpulkan bahwa fixed effect lebih tepat untuk digunakan dalam penelitian ini. Tahapan selanjutnya adalah melakukan uji hausman. Pada pengujian uji hausman, hipotesis yang digunakan adalah sebagai berikut (Yamin dkk., 2011:210):

$\mathrm{H}_{0}:$ Model random effect

$\mathrm{H}_{1}$ : Model fixed effect

Apabila nilai probabilitasnya hasil uji hausman kurang dari tingkat signifikan (5\%) maka $\mathrm{H}_{0}$ ditolak dan $\mathrm{H}_{1}$ diterima,

sehingga model regresi fixed effect yang paling tepat digunakan demikian juga sebaliknya. Berikut hasil uji hausman dengan EViews 9.

Tabel 3.

Hasil Uji Hausman

Correlated Random Effects - Hausman Test

Pool:Untitled

Test cross-section random effects

\begin{tabular}{lrrr}
\hline \hline Test Summary & Chi-Sq. Statistic & Chi-Sq. d.f. & Prob. \\
\hline \hline Cross-section random & 7.116203 & 4 & 0.1299 \\
\hline \hline
\end{tabular}

Sumber: Hasil Regresi Eviews 9

Berdasarkan hasil uji hausman diatas menunjukkan bahwa probabilitas crosssection random sebesar 0,1299>0,05 (dengan tingkat signifikansi $5 \%$ ) sehingga menerima Ho. Berdasarkan hasil uji tersebut dapat disimpulkan bahwa random effect lebih tepat digunakan dalam penelitian ini.

\section{A. Uji Statistik}

Berdasarkan hasil pengujian yang telah dilakukan yaitu uji chow dan uji hausman dengan ketiga model regresi data panel, maka model yang paling tepat digunakan dalam penelitian ini adalah model Random Effect (REM).

Tabel 4.

Hasil Regresi Random Effect Model (REM)

\begin{tabular}{|c|r|r|r|r|}
\hline \multicolumn{5}{|c|}{ Hasil Regresi Random Effect Model } \\
\hline Variabel & Coefficient & Std. Error & t-Statistic & \multicolumn{1}{c|}{ Prob. } \\
\hline C & 4.251338 & 0.520095 & 8.174159 & 0 \\
\hline ROA & -0.001414 & 0.022036 & -0.064175 & 0.949 \\
\hline ROE & 0.00655 & 0.00783 & 0.836503 & 0.4057 \\
\hline NPM & -0.02038 & 0.011389 & -1.789499 & 0.0779 \\
\hline EPS & 0.800691 & 0.094803 & 8.445822 & 0 \\
\hline R2 & 0.619294 & & \\
\hline Adjusted R2 & 0.597539 & \\
\hline F-Statistic & 28.46718 \\
\hline Prob(F-statistic) & 0
\end{tabular}

Sumber: Hasil Regresi Eviews 9, diolah

Setelah mendapatkan model regresi data panel yang tepat lalu dilakukan uji signifikansi untuk mengetahui pengaruh variabel independen terhadap variabel 
Triawan, et al/ Jurnal Ekonomi Syariah Teori dan Terapan Vol. 5 No. 7 Juli 2018: 541-555;

PENGARUH ROA, ROE, NPM DAN EPS TERHADAP HARGA SAHAM DI JAKARTA ISLAMIC INDEX

(JII) PERIODE 2011-2015

dependen yang terdiri dari Uji F, Uji † dan

Uji $R^{2}$. Uji $F$ digunakan untuk mengetahui pengaruh variabel independen secara simultan atau bersama-sama terhadap variabel dependen. Pengujian hipotesis dapat dilakukan dengan konsep p-value atau disebut juga probabilitas. Konsep ini membandingkan a dengan nilai $\mathrm{p}$-value. Jika nilai $p$-value kurang dari $a$, maka $\mathrm{H}_{0}$ ditolak. (Ajija dkk, 2011:34). Adapun hipotesis yang digunakan dalam uji $F$ adalah sebagai berikut:

$\mathrm{H}_{0}$ : Variabel independen tidak terdapat pengaruh secara simultan terhadap variabel dependen. $\mathrm{H}_{1}$ : Variabel independen berpengaruh secara simultan terhadap varibel dependen

Berdasarkan Tabel 4. hasil regresi data panel pada model yang terpilih yaitu model Random Effect (REM) didapatkan prob (F-statistic) sebesar 0,000000 yang lebih kecil dari 0,05 (dengan tingkat signifikansi 5\%), dengan demikian variabel independen yaitu rasio profitabilitas yang terdiri dari: ROA, ROE, NPM dan EPS berpengaruh secara simultan atau bersamaan terhadap variabel dependen (harga saham).

Uji $\dagger$ digunakan untuk mengetahui pengaruh masing-masing variabel independen terhadap variabel dependen secara parsial. Hipotesis yang digunakan dalam uji $\dagger$ adalah sebagai berikut (Ajija dkk, 201 1: 34):

$\mathrm{H}_{0}$ : Variabel independen tidak terdapat pengaruh secara parsial terhadap variabel dependen. $\mathrm{H}_{1}$ : Variabel independen berpengaruh secara parsial terhadap varibel dependen

Berdasarkan Tabel 4. hasil regresi data panel pada model yang terpilih yaitu model random effect (REM) didapatkan hasil bahwa pada tingkat signifikansi $5 \%$ dari empat variabel bebas yang digunakan, hanya variabel EPS saja yang memiliki pengaruh signifikan secara parsial terhadap harga saham yaitu sebesar $0,0000<0,05$ (dengan tingkat signifikansi $5 \%$ ). Pada variabel ROA, ROE dan NPM tidak memiliki pengaruh signifikan karena memiliki nilai probabilitas lebih besar dari 0,05 (dengan tingkat signifikansi 5\%).

Koefisien determinasi atau disebut Rsquared $\left(R^{2}\right)$ digunakan untuk mencerminkan variabel terikat $Y$ dapat diterangkan oleh variabel bebas $X$. Berdasarkan hasil estimasi data panel dengan model Random Effect (REM) diperoleh nilai $R^{2}$ sebesar 0,619294 (61,9294\%). Nilai ini menunjukkan bahwa variabel harga saham (Y) di Jakarta Islamic Index periode 2011-2015 dapat dijelaskan sebesar 61,9294\% oleh variabel independennya, sisanya yaitu sebesar $38,0706 \%$ dipengaruhi oleh variabel lain diluar model.

\section{B. Pengujian Hipotesis}

Berdasarkan hasil analisis regresi data panel model random effect yang telah dilakukan, maka pembuktian hipotesis dapat disimpulkan sebagai berikut:

1) Hipotesis pertama yang menyatakan bahwa ROA, ROE, NPM dan EPS berpengaruh secara parsial terhadap 
Triawan, et al/ Jurnal Ekonomi Syariah Teori dan Terapan Vol. 5 No. 7 Juli 2018: 541-555;

PENGARUH ROA, ROE, NPM DAN EPS TERHADAP HARGA SAHAM DI JAKARTA ISLAMIC INDEX

(JII) PERIODE 2011-2015

harga saham perusahaan di JII pada periode 2011-2015 tidak dapat diterima, berdasarkan uji t statistic hanya variabel EPS saja yang berpengaruh signifikan terhadap harga saham, sehingga hipotesis pertama tidak dapat diterima.

2) Hipotesis kedua yang menyatakan bahwa variabel ROA, ROE, NPM dan EPS berpengaruh secara simultan terhadap harga saham perusahaan di Jll pada periode 2011-2015 dapat diterima, berdasarkan uji F-statistic variabel ROA, ROE, NPM dan EPS secara bersama-sama mempengaruhi harga saham.

\section{Pembahasan}

Berdasarkan Tabel 4. hasil output EViews 9 dengan model Random Effect menyatakan bahwa keempat variabel yang diteliti secara parsial terhadap harga saham, yaitu Return On Assets (ROA), Return On Equity (ROE), Net Profit Margin (NPM) dan Earning Per Share (EPS), hanya EPS saja yang memiliki pengaruh signifikan dan positif terhadap harga saham dengan tingkat signifikansi yang telah ditetapkan yaitu 5\%. Variabel ROA, ROE dan NPM berdasarkan ouput EViews tidak memiliki pengaruh yang signifikan terhadap harga saham.

Tabel 5. Hasil Regresi ROA

\begin{tabular}{|c|c|c|c|c|}
\hline Variabel & Coefficient & Std. Error & t-Statistic & Prob. \\
\hline ROA & -0.001414 & 0.022036 & -0.064175 & 0.949 \\
\hline
\end{tabular}
Sumber: Output Eviews 9, diolah

Variabel Return On Assets (ROA) mempunyai nilai t-statistic sebesar 0,064175 dengan nilai probabilitas 0,9490 lebih besar dari 0,05 (dengan tingkat signifikansi 5\%). Hasil tersebut menunjukkan bahwa Return On Assets (ROA) memiliki hubungan negatif dan tidak signifikan terhadap harga saham. Coefficient ROA sebesar $-0,001414$ sehingga memberikan pengaruh yang negatif terhadap harga saham. Hal tersebut dapat disimpulkan apabila Return On Assets (ROA) mengalami peningkatan sebesar $1 \%$ maka secara rata-rata, harga saham mengalami penurunan sebesar $0,001414 \%$.

ROA yang meningkat tidak membuat tingkat pengembaliannya meningkat dan diikuti dengan harga sahamnya meningkat, melainkan harga sahamnya mengalami penurunan tetapi tidak signifikan. Melihat laporan kevangan, investor harus mengkoreksi dan menghapus aktiva yang tidak memiliki nilai ekonomis dan tidak begitu saja menggunakan angka-angka yang ada dalam laporan keuangan. Karena itu aktiva (assets) yang meningkat tidak menjadi daya tarik investor melakukan investasi.

Tabel 6.

Hasil Regresi ROE

\begin{tabular}{|c|r|r|r|c|}
\hline Variabel & Coefficient & Std. Error & t-Statistic & Prob. \\
\hline ROE & 0.00655 & 0.00783 & 0.836503 & 0.4057 \\
\hline
\end{tabular}

Sumber: Output Eviews 9, diolah

Variabel Return On Equity (ROE) mempunyai nilai t-statistic sebesar 0,836503 dengan nilai probabilitas 0,4057 lebih besar dari 0,05 (dengan tingkat signifikansi 5\%). Hasil tersebut menunjukkan bahwa Return On Equity tidak berpengaruh signifikan terhadap harga saham. Coefficient ROE sebesar 0,006550 sehingga apabila Return On Equity (ROE) 
Triawan, et al/ Jurnal Ekonomi Syariah Teori dan Terapan Vol. 5 No. 7 Juli 2018: 541-555;

PENGARUH ROA, ROE, NPM DAN EPS TERHADAP HARGA SAHAM DI JAKARTA ISLAMIC INDEX

(JII) PERIODE 2011-2015

mengalami peningkatan sebesar 1\%,

maka secara rata-rata, harga saham

mengalami peningkatan sebesar

$0,006550 \%$.

Berdasarkan teori yang dikemukakan oleh Murhadi (2009:87) "Perusahaan dengan retention ratio yang tinggi dan diikuti pula oleh ROE yang tinggi akan memberikan tingkat pertumbuhan yang tinggi pula dalam EPS dan EPS dipengaruhi oleh ROE". Berdasarkan pernyataan tersebut ROE berhubungan positif dengan EPS dalam meningkatkan harga saham. Apabila EPS meningkat maka ROE juga akan meningkat karena memiliki hubungan yang positif. seorang investor melihat bagian keuntungannya bukan dari ROE tetapi dari dividen yang didapatkannya dan dari capital gain ketika saham dijual, karenanya ROE tidak berpengaruh signifikan terhadap harga saham.

Tabel 7.

Hasil Regresi NPM

\begin{tabular}{|c|r|r|c|c|}
\hline Variabel & Coefficient & Std. Error & t-Statistic & Prob. \\
\hline NPM & -0.02038 & 0.011389 & -1.789499 & 0.0779 \\
\hline
\end{tabular}

Sumber: Output Eviews 9, diolah

Variabel Net Profit Margin (NPM) mempunyai nilai t-statistic sebesar 1,789499 dengan nilai probabilitas 0,0779 lebih besar dari 0,05 (dengan tingkat signifikansi $5 \%$ ). Hasil tersebut menunjukkan bahwa Net Profit Margin (NPM) memiliki hubungan negatif dan tidak signifikan terhadap harga saham. Coefficient NPM sebesar -0,020380 sehingga memberikan pengaruh yang negatif terhadap harga saham. Hal tersebut dapat disimpulkan apabila Net Profit Margin mengalami

peningkatan sebesar $1 \%$, maka secara rata-rata, harga saham mengalami penurunan sebesar $0,020380 \%$.

Perusahaan dengan marjin laba (NPM) yang rendah akan memiliki tingkat pengembalian yang lebih tinggi kepada pemegang saham karena menggunakan leverage keuangan (pembiayaan dengan utang) (Brigham dan Houston, 2001:90). Karenanya, NPM memiliki hubungan negatif dan tidak signifikan terhadap harga saham.

Tabel 8.

Hasil Regresi EPS

\begin{tabular}{|c|r|r|r|r|}
\hline Variabel & Coefficient & Std. Error & t-Statistic & Prob. \\
\hline EPS & 0.800691 & 0.094803 & 8.445822 & 0 \\
\hline
\end{tabular}

Sumber: Output Eviews 9, diolah

Variabel Earning Per Share (EPS) mempunyai nilai t-statistic sebesar 8,445822 dangan nilai probabilitas 0,0000 lebih kecil dari 0,05 (dengan tingkat signifikansi $5 \%)$. Hasil tersebut menunjukkan bahwa Earning Per Share berpengaruh positif dan signifikan terhadap harga saham. Coefficient EPS sebesar 0,800691 sehingga apabila Earning Per Share mengalami peningkatan sebesar $1 \%$, maka secara rata-rata, harga saham mengalami peningkatan sebesar $0,800691 \%$.

Bagi para investor, informasi EPS merupakan informasi yang dianggap paling mendasar dan berguna, karena bisa menggambarkan prospek earning perusahaan di masa depan (Tandelilin, 2010:365). Kemajuan dan kemunduran perusahaan akan direspon oleh pasar melalui perubahan harga saham (Samsul, 2015:189). Kemajuan perusahaan yang 
Triawan, et al/ Jurnal Ekonomi Syariah Teori dan Terapan Vol. 5 No. 7 Juli 2018: 541-555;

PENGARUH ROA, ROE, NPM DAN EPS TERHADAP HARGA SAHAM DI JAKARTA ISLAMIC INDEX (JII) PERIODE 2011-2015

ditandai dengan meningkatnya EPS akan membuat permintaan investor terhadap saham tersebut meningkat sehingga membuat harga sahamnya meningkat karena dipengaruhi oleh hukum permintaan dan penawaran, dengan demikian EPS berpengaruh secara positif dan signifikan terhadap harga saham.

Berdasarkan Tabel 4. hasil output dari EViews model random effect (REM) keseluruhan variabel independen (empat variabel) yang diteliti terdiri dari Return On Assets (ROA), Return On Equity (ROE), Net Profit Margin (NPM) dan Earning Per Share (EPS) pengaruhnya terhadap harga saham menunjukkan secara simultan memiliki angka prob(F-statistic) sebesar 0,000000 lebih kecil dari 0,05 (dengan tingkat signifikansi $5 \%$ ) yang artinya variabel ROA, ROE, NPM dan EPS secara bersama-sama berpengaruh terhadap harga saham. Hasil koefisien determinasi $\left(R^{2}\right)$ yang bernilai 0,619294 atau 61,9294\%, hal ini menunjukkan bahwa variabel terikat dalam penelitian ini adalah harga saham di Jakarta Islamic Index dapat dijelaskan oleh variabel bebas, dalam penelitian ini adalah ROA, ROE, NPM dan EPS sebesar 61,9294\%. Hal ini menandakan bahwa variabel lain diluar model masih berpotensi cukup besar untuk mempengaruhi harga saham, yaitu sebesar $38,0706 \%$.

Melihat pernyataan diatas, dimana harga saham dapat dijelaskan oleh variabel ROA, ROE, NPM dan EPS sebesar $61,9294 \%$ dan sisanya dijelaskan oleh variabel lain diluar model, maka peneliti melihat variabel-variabel lain masih berpotensi cukup besar mempengaruhi harga saham. Variabel lain yang memungkinkan

berpotensi mempengaruhi harga saham diantaranya Faktor Makro yang berada di luar perusahaan antara lain: tingkat bunga, tingkat inflasi, kurs valuta asing, kondisi perekonomian internasional. Kondisi siklus ekonomi juga memungkinkan berpotensi mempengaruhi harga saham. Dalam siklus ekonomi yang tumbuh setiap bidang usaha memperoleh kemajuan, lapangan kerja tersedia banyak, pendapatan masyarakat meningkat sehingga bursa efek menjadi semarak, sehingga harga saham mengalami kanaikan sepanjang periode kemakmuran (Samsul, 2006:204).

\section{SIMPULAN}

Berdasarkan penjelasan hasil penelitian dan pembahasan tentang pengaruh ROA, ROE, NPM dan EPS terhadap harga saham perusahaan di Jakarta Islamic Index (JII) periode 20112015, menghasilkan kesimpulan sebagai berikut:

ROA, ROE, NPM dan EPS secara simultan atau bersama-sama berpengaruh terhadap harga saham perusahaan di JII pada periode $2011-2015$. Hasil penelitian menyimpulkan secara simultan melalui uji $\mathrm{F}$ memiliki probabilitas sebesar 0,000000 < 0,05 ROA, ROE, NPM dan EPS secara keseluruhan atau simultan akan menarik perhatian investor yang diikuti dengan bertambahnya permintaan terhadap saham dan akan berpengaruh terhadap harga sahamnya. 
Triawan, et al/ Jurnal Ekonomi Syariah Teori dan Terapan Vol. 5 No. 7 Juli 2018: 541-555;

PENGARUH ROA, ROE, NPM DAN EPS TERHADAP HARGA SAHAM DI JAKARTA ISLAMIC INDEX

(JII) PERIODE 2011-2015

ROA, ROE, NPM tidak memiliki

Darmadji, Tjiptono \& Hendy M Fakhruddin.

pengaruh yang signifikan terhadap harga saham, hanya EPS yang memiliki pengaruh signifikan terhadap harga saham di Jakarta Islamic Index periode 2011-2015. Hasil penelitian menyimpulkan bahwa Return On Assets (ROA) memiliki hubungan negatif dan tidak signifikan terhadap harga saham. Hasil penelitian Return On Equity (ROE) menyimpulkan secara parsial memiliki hubungan positif dan tidak signifikan terhadap harga saham. Hasil penelitian Net Profit Margin (NPM) menyimpulkan secara parsial memiliki hubungan negatif dan tidak signifikan terhadap harga saham. Hasil penelitian Earning Per Share (EPS) menyimpulkan secara parsial memiliki hubungan positif dan signifikan terhadap harga saham.

\section{DAFTAR PUSTAKA}

Ajija, Shochrul R dkk. 2011. Cara Cerdas Menguasai EViews. Jakarta: Salemba Empat

Anshori, Muslich \& Sri Iswati. 2009. Buku Ajar Metodologi Penelitian Kuantitatif. Surabaya: Airlangga University Press

Basuki, Agus Tri \& Nano Prawoto. 2016. Analisis Regresi Dalam Penelitian Ekonomi \& Bisnis (Dilengkapi Aplikasi SPSS \& EVIEWS). Depok: Rajawali Pers

Brigham, Eugene F. \& Joel F. Houston. 2001. Manajemen Keuangan, terjemahan Dodo Suharto \& Herman Wibowo Edisi Kedelapan Buku 1. Jakarta: Erlangga 
Triawan, et al/ Jurnal Ekonomi Syariah Teori dan Terapan Vol. 5 No. 7 Juli 2018: 541-555;

PENGARUH ROA, ROE, NPM DAN EPS TERHADAP HARGA SAHAM DI JAKARTA ISLAMIC INDEX

(JII) PERIODE 2011-2015

dan EVIEWS. Depok: Fakultas Ekonomi

Universitas Indonesia

Redaksi, Sinar Grafika. 2003. Himpunan Peraturan Pasar Modal UU No. 8 Th. 1995 tentang Pasar Modal. Jakarta: Sinar Grafika

Samsul, Mohamad. 2006. Pasar Modal \& Manajemen Portofolio. Jakarta:

Erlangga

2015. Pasar Modal \& Manajemen Portofolio Edisi 2. Jakarta: Erlangga

Sarwoko. 2005. Dasar-Dasar Ekonometrika. Yogyakarta: Andi

Sjahrial, Dermawan. 2012. Pengantar Manajemen Keuangan. Jakarta: Mitra Wacana Media

Soemitra, Andri. 2009. Bank \& Lembaga Kevangan Syariah. Jakarta: Kencana Prenada Media Goup

Sudana, I Made. 2009. Manajemen Keuangan Teori Dan Praktik. Surabaya: Airlangga University Press

Sugiyono. 2014. Metode Penelitian Bisnis. Bandung: Alfabeta Penerbit

Sutedi, Adrian. 2011. Pasar Modal Syariah. Jakarta: Sinar Grafika

Tandelilin, Eduardus. 2010. Portofolio dan Investasi Teori dan Aplikasi. Yogyakarta: Kanisius

Weston, J. Fred \& Thomas E. Copeland. 1988. Manajemen Keuangan, terjemahan Jaka Wasana dan Kirbrandoko, Edisi Kedelapan. Jakarta: Erlangga

Yamin, Sofyan dkk. 2011. Regresi dan Korelasi dalam Genggaman Anda. Jakarta: Salemba Empat https://finance.yahoo.com

http://www.idx.co.id

http://www.syariahsaham.com/2015/06/9hal-yang-perlu-anda-ketahui-tentang.html 